\title{
ZAŠTITA NACIONALNOG BLAGA KAO IZUZETAK OD SLOBODE KRETANJA ROBE U EVROPSKOJ UNIJI
}

\author{
Vanja PAVIĆEVIĆ* \\ Mihajlo VUČIĆ**
}

\begin{abstract}
Apstrakt: Sloboda kretanja robe u Evropskoj uniji predstavlja ključnu slobodu, neophodnu za razvoj carinske unije i jedinstvenog tržišta. Svojim širokim tumačenjem kvantitativnih ograničenja i mera ekvivalentnog efekta, razgraničenjem pojma direktne i indirektne diskriminacije na tržištu EU, Sud pravde odigrao je važnu ulogu u produbljivanju zaštite slobodnog kretanja robe. Shodno tome, radi izbegavanja eventualnih zloupotreba navedene slobode, svaka vrsta izuzetka mora se usko tumačiti. Izuzeci od slobodnog prometa robe uglavnom se odnose na razloge javnog morala, bezbednosti, zaštite zdravlja i života ljudi, životinja, biljaka, ali se mogu odnositi i na zaštitu kulturnih dobara države koja su klasifikovana kao „nacionalno blago”. U potonjem slučaju, Sud se uzdržao od generalnih smernica pri tumačenju člana 36 koji predviđa izuzetak u vidu nacionalnog blaga koje ima umetničku, istorijsku ili arheološku vrednost. Imajući to u vidu, predmet rada jeste pronalaženje delikatnog balansa između proklamovane slobode kretanja robe u EU i specifične zaštite koju uživaju kulturna dobra. Pre svega, analiziraćemo postojeći pravni okvir povrata kulturnih dobara
\end{abstract}

\footnotetext{
* Vanja Pavićević, istraživač-saradnik, Institut za međunarodnu politiku i privredu, Beograd, e-mail: vanja.pavicevic@diplomacy.bg.ac.rs.

Rad je nastao u okviru naučnoistraživačkog projekta „Srbija i izazovi u međunarodnim odnosima 2021. godine”, koji finansira Ministarstvo prosvete, nauke i tehnološkog razvoja Republike Srbije, a realizuje Institut za međunarodnu politiku i privredu tokom 2021. godine.

** Mihajlo Vučić, viši naučni saradnik, Institut za međunarodnu politiku i privredu, Beograd, e-mail: mihajlo@diplomacy.bg.ac.rs.
} 
u EU. Zatim, istražićemo povezanost mehanizma povrata kulturnih dobara sa konceptom nacionalnog blaga u svetlu člana 36 UFEU. Konačno, kritički ćemo ispitati koncept „nacionalnog blaga”, kao izuzetka od zabrane ograničenja slobodnog prometa robe. U tom svetlu, prikazaćemo razvoj evropskog zakonodavstva u građenju šire mreže zaštite kulturnih dobara.

Ključne reči: Direktiva 2014/60/EU, povrat kulturnih dobara, nacionalno blago, slobodan promet robe, UNIDROIT 1995

\section{1) UVOD}

Nadležnost Evropske unije (u daljem tekstu: EU) u pogledu kulture propisana je članom 167 Ugovora o funkcionisanju EU (u daljem tekstu: UFEU), a kojim se EU obavezuje da poštuje nacionalni i regionalni diverzitet država članica, podstiče njihovu međusobnu saradnju, usvaja podsticajne mere, savetuje, pomaže i slično. ${ }^{1}$ Dakle, EU u tom smislu ne poseduje isključivu, već komplementarnu nadležnost. Stoga, svaka država članica poseduje zakonodavnu i regulatornu slobodu u polju kulturne politike, te pravo da samostalno definiše i štiti svoje materijalno i nematerijalno kulturno nasleđe. S druge strane, nadležnost EU pojačana je kada je reč o prometu kulturnih dobara. Ovakva nadležnost prirodno proističe iz nadležnosti EU da reguliše jedinstveno tržište, slobodan promet robe, te samim time i promet kulturnih dobara. Zajedničko tržište, kao raison d'être stvaranja Evropske unije, zasniva se na četiri dobro poznata stuba: slobode kretanja robe, lica, usluga i kapitala. No, sloboda kretanja robe svakako predstavlja ključnu slobodu, koja omogućava ostvarivanje ciljeva carinske unije i funkcionisanja jedinstvenog tržišta grosso modo. ${ }^{2}$ Stoga su između država članica EU zabranjene uvozne i izvozne carine, dok je za njihovo istupanje prema trećim zemljama predviđena zajednička carinska tarifa. ${ }^{3}$ Zabrana kvantitativnih ograničenja država članica u njihovom slobodnom prometu robe predstavljena je u članovima 34-37 UFEU, dok su u članu 36 UFEU nabrojani eventualni izuzeci od takve zabrane. Upravo je pomenuti član 36 UFEU od posebne važnosti za centralnu temu ovog rada, i on glasi:

Odredbe čl. 34 i 35 ne isključuju zabrane ili ograničenja uvoza, izvoza ili tranzita robe koji su opravdani razlozima javnog morala, javnog poretka ili javne bezbednosti; zaštite zdravlja i života ljudi, životinja ili biljaka; zaštite

\footnotetext{
${ }^{1}$ Ugovor o funkcionisanju Evropske unije, https://www.mei.gov.rs/upload/documents/ eu_dokumenta/ugovor_o_eu_i_funkcionisanju_eu_prociscena_verzija_jul_20.pdf, pristupljeno 1. februar 2021. godine ("Consolidated version of the Treaty on the Functioning of the European Union", Official Journal C 326 , 26/10/2012 P. 0001 - 0390.)

${ }^{2}$ Čl. 26, st. 2. UFEU navodi najpre slobodu kretanja robe kao deo jedinstvenog tržišta.

${ }^{3}$ Ibid., čl. 28, st. 1. (bivši član 23 TEC).
} 
nacionalnog blaga koje ima umetničku, istorijsku ili arheološku vrednost ili zaštite industrijske i komercijalne svojine. Međutim, takve zabrane ili ograničenja ne smeju predstavljati sredstvo proizvoljne diskriminacije ili prikriveno ograničavanje trgovine između država članica. ${ }^{4}$

Ovako uopšteno navedene sintagme u vidu izuzetaka predstavljaju plodno tlo za eventualne zloupotrebe država članica, koje su neretko pokušavale da njihovom primenom nametnu ograničenja u prometu robe, pravdajući ih potrebom zaštite sopstvenih trgovinskih interesa. U tom svetlu, značajnu ulogu je odigrao Sud pravde Evropske unije (u daljem tekstu kao: Sud), i to ne samo u razvoju carinske unije i jedinstvenog tržišta. Svojim širokim tumačenjem kvantitativnih ograničenja i mera ekvivalentnog efekta, razgraničenjem pojma direktne i indirektne diskriminacije na EU tržištu, Sud je odigrao važnu ulogu u produbljivanju zaštite slobodnog kretanja robe..$^{5}$ Ipak, kada je reč o prometu kulturnih dobara, Sud je postupao sa više opreza. Naime, Sud se uzdržao od generalnih smernica pri opširnijem tumačenju člana 36 UFEU, odnosno nacionalnog blaga koje ima umetničku, istorijsku ili arheološku vrednost. Ono što predstavlja poseban problem jeste činjenica da se mnogi EU propisi koji se bave zaštitom kulturnih dobara pozivaju upravo na sporni član 36 UFEU i njegovu uopštenu definiciju nacionalnog blaga. Daljim 'prepisivanjem' ove maglovite definicije, predviđeni izuzetak nacionalnog blaga postao je svojevrsna tačka spoticanja na široj mapi zaštite kulturnih dobara u EU.

Stoga, cilj ovog rada jeste dvojak: s jedne strane, analiziraćemo postojeći pravni okvir povrata kulturnih dobara u EU, kao i njegovu povezanost sa konceptom nacionalnog blaga. $S$ druge strane, kritički ćemo ispitati koncept „nacionalnog blaga", kao izuzetka od zabrane ograničenja slobodnog prometa robe. U tom svetlu, prikazaćemo razvoj evropskog zakonodavstva u pokušaju da se dostigne delikatni balans između proklamovane slobode kretanja robe i zaštite kulturnih dobara. ${ }^{6}$

\footnotetext{
${ }^{4}$ Ibid., čl. 36.

${ }^{5}$ Uloga Suda u jačanju slobode kretanja robe putem jasnog prepoznavanja i ukidanja kako kvantitativnih ograničenja uvoza i izvoza između država članica tako i mera ekvivalentnog efekta, posebno je došla do izražaja u sada već čuvenim slučajevima Dassonville (Case 8/74 Procureur du Roi v Dassonville [1974] ECR 837), Cassis de Dijon, (Case 120/78 Rewe-Zentral v Bundesmonopolverwaltung für Branntwein (Cassis de Dijon) [1979] ECR 649), kao i Commission vs Ireland (Case 249/81 Commission v Ireland [1982] ECR 4005). Vidi više: Paul Philip Craig, Gráinne de Búrca, EU Law: Text, Cases, and Materials, $5^{\text {th }}$ edition, Oxford University Press, New York, 2011, pp. 611-692.

${ }^{6}$ Kada je reč o međunarodnom pravu, pitanjem povrata bavi se posebno telo, specijalno osnovan UNESCO međudržavni komitet za promociju povrata kulturnih dobara u zemlje porekla, ili njihov povraćaj u slučaju protivpravnog prisvajanja (eng. Intergovernmental Committee for Promoting the Return of Cultural Property to its Countries of Origin or its Restitution in case of Illicit Appropriation).
} 


\section{2) SKROMNI POČECI - DIREKTIVA 93/7/EEC O POVRATU KULTURNIH DOBARA NEZAKONITO IZNETIH SA TERITORIJE DRŽAVE ČLANICE}

Kulturna dobra en général, kroz svoju burnu istoriju nisu samo predstavljala inspiraciju koja je slavljena, analizirana i neretko kopirana, već su često bila i kolateralna šteta usled ratova, oružanih sukoba, pljački i tome slično. Proces dekolonizacije, koji je kasnije usledio, doprineo je podizanju svesti o 'vlasništvu' nad kulturnim dobrima, te postavio brojna etička, moralna, ali i pravna pitanja o njegovoj 'zemlji porekla'. Ipak, fenomen krađe i krijumčarenja kulturnih dobara nije zaobišao ni evropski kontinent. Nakon Napoleonovih osvajanja i Bečkog kongresa 1815. godine, obaveza povrata kulturnih dobara zemljama porekla ponovo je potvrđena u mirovnim ugovorima koji su zaključivani nakon Prvog svetskog rata. ${ }^{7}$ Danas, u XXI veku, čini se da je pitanje porekla, vlasništva i zaštite kulturnih dobara aktuelnije nego ikada pre, a pogotovo imajući u vidu tendenciju da se isprave određene istorijske i ratne nepravde. Međutim, takva nastojanja otežava činjenica da je krijumčarenje kulturnih dobara postala jedna od najunosnijih kriminalnih aktivnosti, čemu svakako ide u prilog olakšan promet robe između država članica EU. Stoga, put do razvoja mehanizama za povrat kulturnih dobara u zemlje porekla nije bio pravolinijski, i ne bez određenih poteškoća, pa čak i kritika na račun EU institucija. U našem istraživanju fokusiraćemo se na materijalna, pokretna kulturna dobra, budući da su ona uglavnom najpodložnija nezakonitom izvozu.

Naime, 1993. godine doneta je Direktiva Saveta 93/7/EEZ o povratu kulturnih dobara nezakonito iznetih sa teritorije države članice (u daljem tekstu kao: Direktiva 93/7). ${ }^{8}$ Direktiva 93/7, zajedno sa ranije važećom Uredbom Saveta

${ }^{7}$ „Član 248 Versajskog sporazuma od 28. juna 1919. godine između savezničkih sila i Nemačke uspostavio je pravni lek za povraćaj onih predmeta oduzetih tokom rata koji su i dalje postojali, i koje je bilo moguće identifikovati." Alessandro Chechi, "The Return of Cultural Objects Removed in Times of Colonial Domination and International Law: The Case of the Venus of Cyrene", Italian Yearbook of International Law, Vol. XVIII, 2008, pp. 165-166.

8 "Council Directive 93/7/EEC on the return of cultural objects unlawfully removed from the territory of a Member State", Official Journal of the European Union, L74, 15 March 1993. Budući da ne postoji zvaničan prevod na srpski jezik pomenute Direktive, autorka je stanovišta da je imajući u vidu smisao i cilj odredbi, najadekvatnji prevod sintagme 'return to the country of origin' jeste termin 'povrat u zemlju porekla'. Dakle, reč je o donekle pravno neutralnom terminu (za razliku od restitucije), koji označava povrat onih kulturnih dobara koja su izneta iz zemlje tokom kolonijalnog perioda, ili koja su odavno izvezena iz zemlje porekla. Prema članu 2, stavu 5 Direktive, „povrat” znači fizički povrat kulturnog predmeta na državno područje države članice koja je zatražila povrat. 
3911/92 o izvozu kulturnih dobara, ${ }^{9}$ primarno je težila da dopuni postojeću zaštitu koju su pružala fragmentisana nacionalna pravila, a pre uspostavljanja jedinstvenog evropskog tržišta. ${ }^{10}$ Međutim, Direktiva 93/7 pokazala se nedovoljno efikasnom u praksi, i to na različitim frontovima. Pre svega, ona se odlikovala veoma kratkim vremenskim periodom u kojem je država članica morala da podnese zahtev za povrat - samo godinu dana nakon saznanja o lokaciji kulturnog dobra i identitetu držaoca istog. ${ }^{11}$ Reč je o veoma kratkom roku, koji ne ostavlja dovoljno vremena nadležnim organima države koja zahteva povrat za prikupljanje relevantnih informacija o lokaciji i držaocu, kontaktiranje države u kojoj se dobro nalazi, provere autentičnosti dobra, i tome slično. Tako kratki rokovi zapravo idu u korist nezakonitom držaocu, te podstiču pravnu nesigurnost i nelegalno tržište kulturnih dobara.

Dalje, posebnu ograničavajuću okolnost predstavljao je 'ozloglašeni' aneks Direktive 93/7 koji je propisivao kategorije starosti i finansijske vrednosti koje je kulturno dobro moralo da se ispuni kako bi bilo pogodno za povrat. Dakle, pored opšteg uslova da kulturno dobro mora najpre biti definisano od strane države članice koja zahteva povrat kao „nacionalno blago umetničke, istorijske ili arheološke vrednosti" (u skladu sa čl. 36 UFEU), Direktiva 93/7 nametala je kumulativan uslov u vidu pomenutih kategorija sadržanih u aneksu. Na primer, da bi predstavljale kulturno dobro, knjige su morale biti starije od 100 godina, vrednije od 50.000 evra i slično, dok je finansijska procena vršena u odnosu na uslove tržišta u državi članici od koje se zahteva povrat. Alternativno, ukoliko sporno kulturno dobro nije spadalo u aneksom predviđene kategorije, a država ga jeste označila kao „nacionalno blago", moralo je biti ocenjeno kao 'deo javne zbirke koja je navedena u muzejskim inventarima, arhivima, ili konzervatorskim kolekcijama. ${ }^{.12}$

Ipak, smeštanje kulturnih dobara u vrednosne i starosne kalupe nije se pokazalo kao dobar instrument zaštite. Na primer, određena kulturna dobra koja

${ }^{9}$ Ova Uredba kasnije je zamenjena Uredbom Saveta br.116/2009, od 18. decembra 2008. godine, Council Regulation (EC) No. 116/2009 of 18 December 2008 on the export of cultural goods (codified version), OJ L 39, 10.2.2009.

${ }^{10}$ Marina Schneider, "The 1995 UNIDROIT Convention: An Indispensable Complement to the 1970 UNESCO Convention and an Inspiration for the 2014/60/EU Directive", Santander Art and Culture Law Review, 2/2016 (2), p. 158.

11 "Council Directive 93/7/EEC on the return of cultural objects unlawfully removed from the territory of a Member State", član 7, stav 1.

${ }^{12}$ Javne kolekcije se definišu kao kolekcije koje su u vlasništvu države članice, lokalne ili regionalne vlasti ili institucije na njenoj teritoriji, i koje su definisane kao javne u skladu sa zakonodavstvom te države članice. Alternativno, kulturno dobro mora predstavljati sastavni deo inventara crkvenih institucija. "Council Directive 93/7/EEC on the return of cultural objects unlawfully removed from the territory of a Member State", op. cit., član 1. 
zaista zavređuju zaštitu i koja su označena od strane države kao „,nacionalno blago”, mogu lako biti izostavljena ukoliko ne spadaju u date kategorije, ili nisu deo javne zbirke. To je i primećeno i u trogodišnjim Izveštajima o efikasnosti koje je izrađivala Evropska komisija, gde su visoki troškovi i administrativna složenost Direktive 93/07 takođe označeni kao glavni 'krivci' za njenu retku i neefikasnu primenu. ${ }^{13}$ Često se navodi i to da je Direktiva 93/07 bila potencijalno značajna samo za države koje nisu ratifikovale UNIDROIT 1995 Konvenciju o ukradenim ili nelegalno izvezenim predmetima od kulturnog značaja (u daljem tekstu kao UNIDROIT Konvencija 1995) ${ }_{1}^{14}$ kao što je to npr. Poljska. ${ }^{15}$ Ipak, određeni autori navode kako Direktiva 93/07 nije bila potpuno beskorisna, jer je, pored određenog broja dobrovoljnih povrata, pokazala stvarnu političku volju da se na evropskom unutrašnjem tržištu zaštiti kulturno nasleđe. ${ }^{16}$ Može se zaključiti da je pomenuti Aneks svojim donekle rigidnim uslovima izostavio veliki deo kulturnih dobara, što je posledično dovelo do veoma otežane primene Direktive 93/7 u praksi.

\section{3) JAČANJE PRAVNOG OKVIRA - DIREKTIVA 2014/60 EU O POVRATU KULTURNIH DOBARA}

Nakon nekoliko izmenjenih verzija, brojnih kritika i neuspelih procesa povrata, Direktiva 93/7 konačno je izmenjena i donet je novi instrument sekundarnog prava EU: Direktiva 2014/60 o povratu kulturnih dobara nezakonito iznetih sa teritorije države članice (u daljem tekstu kao: Direktiva 2014/60). ${ }^{17}$ Direktiva

${ }^{13}$ (...) Moreover, most of the Member States blamed the administrative complexity and cost of applying the Directive for the fact that it is seldom used. According to these Member States, this is why the national authorities prefer to use civil or criminal proceedings. Furthermore, some Member States, such as France, Italy and Hungary, take the view that limiting the scope of the Directive to national treasures listed in the Annex to the Directive or belonging to public collections or on ecclesiastical lists constitutes a further restriction (...) "Third Report from the Commission to the European Parliament, the Council and the European Economic and Social Committee on the application of Council Directive 93/7 on the return of cultural objects unlawfully removed from the territory of a Member State", Bruxelles, 30 July 2009, COM/2009/0408 final.

${ }^{14}$ UNIDROIT Convention on Stolen or Illegally Exported Cultural Objects, 24 June 1995, https://www.unidroit.org/instruments/cultural-property/1995-convention, pristupljeno: 5. februara 2021. godine.

${ }^{15}$ Olgierd Jakubowski, "The Internal Market Information System (IMI) on the Return of Cultural Objects - Its Principles, Application, and Evaluation of Its Effectiveness for the Protection of Cultural Heritage", Santander Art and Culture Law Review, 2/2016 (2), p. 293.

${ }^{16}$ Geo Magri, "Directive 2014/60/EU and Its Effects on the European Art Market", Santander Art and Culture Law Review, 2/2016 (2), p. 203.

17 "Directive 2014/60/EU of the European Parliament and of the Council of 15 May 2014 on the return of cultural objects unlawfully removed from the territory of a Member State and 
2014/60 ciljano deluje na nedostatke svoje prethodnice, pa tako unosi mnoštvo pozitivnih novina u procesu povrata kulturnih dobara. Pre svega, Direktiva 2014/60 produžava vremenski period u kojem država članica može pokrenuti proceduru povrata, te je rok za povrat sada tri godine od momenta saznanja o lokaciji kulturnog dobra i identitetu držaoca, isto kao i u UNIDROIT 1995 Konvenciji. Produženi rok predstavlja odlično rešenje, budući da je prethodni rok od godinu dana bio svakako jedna od najslabijih karika Direktive 93/7, ako ne i najslabija, a pogotovo imajući u vidu složene administrativne procedure i troškove samog povrata. Apsolutni rok zastarelosti od 30 godina je zadržan.

Dalje, konačno se napušta primena starosnih i finansijskih kriterijuma iz prethodne Direktive. Stoga, nova Direktiva može se primeniti na ... bilo koja kulturna dobra koja je država članica, u okviru svog nacionalnog zakonodavstva ili upravnih procedura klasifikovala ili definisala kao nacionalno blago umetničke, istorijske ili arheološke vrednosti u smislu čl. 36 UFEU...(...)... bez obzira na to da li su deo javne ili druge zbirke ili su pojedinačni predmeti, te da li potiču iz redovnih ili tajnih iskopavanja, pod uslovom da su klasifikovani ili definisani kao nacionalno blago (...). ${ }^{18}$

Odluka da se napusti primena aneksa bila je praćena gorućom raspravom u nadležnom odboru Evropskog parlamenta jer predstavlja značajno proširenje evropskog zakonodavnog dometa u oblasti povrata kulturnih dobara. ${ }^{19}$ Dakle, kada je reč o definiciji kulturnog dobra, Direktiva 2014/60 se poziva direktno na postojeću definiciju iz člana 36 UFEU, i ne propisuje dodatne uslove koje objekat mora posedovati da bi bio pogodan za povrat. Jedini uslov jeste da je reč o nacionalnom blagu umetničke, istorijske ili arheološke vrednosti, što ćemo detaljnije analizirati u nastavku rada.

Takođe, Direktiva 2014/60 uvodi jednu značajnu novinu i prenosi teret dokazivanja dužne pažnje (due dilligence) na držaoca kulturnog dobra. ${ }^{20}$ Opravdanje za novi pristup počiva na ideji da je lakše da držalac podnese pozitivan dokaz da je postupao sa potrebnom pažnjom (npr. da je proverio da li je kulturno dobro navedeno u registru nelegalno izvezenih objekata i sl.), nego da država koja zahteva povrat dokazuje negativno, tj. da se držalac nije pridržavao određenih

amending Regulation (EU) No 1024/2012 (Recast)", Official Journal of the European Union, L 159/1, May, 2014.

${ }^{18}$ Ibid., preambula, tačka 9.

${ }^{19}$ Manlio Frigo, "The Implementation of Directive 2014/60/EU and the Problems of the Compliance of Italian Legislation with International and EU Law", Santander Art and Culture Law Review, 2/2016 (2), p. 73.

${ }^{20}$ Article 10, "Directive 2014/60/EU of the European Parliament and of the Council of 15 May 2014 on the return of cultural objects unlawfully removed from the territory of a Member State and amending Regulation (EU) No 1024/2012 (Recast)". 
standardnih procedura tokom sticanja kulturnog dobra. ${ }^{21}$ Ukoliko se pridržavao datih procedura, držalac ima pravo na kompenzaciju. Ono što se, ipak, može zameriti ovom rešenju jeste nedorečenost u pogledu toga šta uopšte predstavlja poštena kompenzacija, kao i pomoću kojih parametara se može odrediti, što inače predstavlja veoma aktuelno pitanje u međunarodnom pravu kulturnog nasleđa.

Pozitivna novina predstavlja i koherentnije razrađen standard dužne pažnje, te se navode konkretne činjenice koje će se ceniti prilikom njegove procene, premda lista nije konačna. To je učinjeno po ugledu na UNIDROIT 1995 Konvenciju, koja propisuje identične kriterijume za procenu dužne pažnje (samo što potonja to čini u slučaju krađe). ${ }^{22}$ Reč je o inovativnom pristupu evropskog zakonodavca koji je želeo da, pružajući smernice sudovima, donekle standardizuje tumačenje pojma dužne pažnje prilikom njegove procene. ${ }^{23}$ Direktiva 2014/60 dodaje još jedan uslov u proceni dužne pažnje, a to je da se dozvole za iznošenje kulturnog dobra procenjuju prema pravu države članice koja je zatražila povrat, što možda čini UNIDROIT 1995 Konvenciju čak donekle 'popustljivijom' u odnosu na Direktivu 2014/60. ${ }^{24}$

Kada je reč o obavezi saradnje između država članica, može se reći da je ona donekle ojačana ali i olakšana u odnosu na prethodnu Direktivu 93/07. ${ }^{25}$ Dakle, član 5 Direktive 2014/60 koji predviđa mogućnost arbitražnog rešavanja spora između države koja zahteva povrat i držaoca, a uz posredovanje države na čijoj teritoriji se kulturno dobro nalazi, u poslednjem stavu sadrži interesantnu i korisnu novinu. Naime, nadležni organi države članice obavezuju se da u pogledu sredstava razmene informacija između država članica koriste Informacioni sistem unutrašnjeg tržišta (Internal Market Information System - u daljem tekstu kao IMI), a koji je posebno prilagođen za kulturna dobra. ${ }^{26} \mathrm{U}$ pitanju je softverska internet

${ }^{21}$ Olgierd Jakubowski, "The Internal Market Information System (IMI) on the Return of Cultural Objects - Its Principles, Application, and Evaluation of Its Effectiveness for the Protection of Cultural Heritage", op. cit., p. 295.

${ }^{22}$ Marina Schneider, "The 1995 UNIDROIT Convention: An Indispensable Complement to the 1970 UNESCO Convention and an Inspiration for the 2014/60/EU Directive", op. cit., p.161.

${ }^{23}$ Geo Magri, "The impact of the UNESCO and UNIDROIT Conventions and the EU directives on the international art market: an analysis fifty years after the introduction of the obligation to return stolen or illegally exported cultural goods", Brazilian Journal of International Law, Vol. 17 , no. 3,2020 , p. 71 .

${ }^{24}$ Ibid.

${ }^{25}$ Olgierd Jakubowski, “The Internal Market Information System (IMI) on the Return of Cultural Objects - Its Principles, Application, and Evaluation of Its Effectiveness for the Protection of Cultural Heritage", op. cit., p. 296.

${ }^{26}$ In particular, IMI helps competent authorities to identify their counterpart in another Member State, to manage the exchange of information, including personal data, on the basis of simple 
aplikacija razvijena od strane Evropske komisije, u cilju pružanja pomoći državama članicama prilikom saradnje i razmene informacija. Države članice moraju u skladu sa sopstvenom administrativnom strukturom, imenovati bar jednog (ili više ukoliko raspolažu kapacitetima) IMI koordinatora. Preambula Direktive 2014/60 čak predviđa osnivanje grupe eksperata, koju čine organi država članica nadležni za njenu implementaciju, ali koji će biti istovremeno uključeni u proces prilagođavanja IMI sistema za kulturna dobra. Ovakva informaciona novina predstavlja veoma važnu kariku u složenom lancu zaštite, a pogotovo imajući u vidu da je blagovremena (neretko i hitna) razmena informacija između nadležnih organa presudna za povrat kulturnih dobara. IMI sistem se, pored povrata kulturnih dobara, koristi u 11 oblasti EU prava. ${ }^{27}$

\section{4) MREŽA ZAŠTITE KULTURNIH DOBARA U EU - (NE)USKLAĐENOST?}

Direktiva 2014/60 je u poređenju sa svojom prethodnicom, Direktivom 1993/7, svakako postavila znatno jače temelje zaštite kulturnih dobara, te učinila proces povrata efikasnijim, lakšim i povoljnijim za državu članicu koja isti zahteva. Međutim, kako bismo što sveobuhvatnije analizirali potencijalnu neusklađenost koja postoji u EU zakonodavstvu, neophodno je sadržaj Direktive 2014/60 tumačiti u svetlu ostalih međunarodnih i EU instrumenata koji se primenjuju u ovoj oblasti.

\subsection{UNIDROIT 1995 KONVENCIJA O UKRADENIM ILI ILEGALNO IZVEZENIM PREDMETIMA OD KULTURNOG ZNACAJA}

Na osnovu izložene analize Direktive 2014/60, može se primetiti da su mnoga rešenja inspirisana UNIDROIT 1995 Konvencijom, što i ne čudi imajući u vidu da

and unified procedures and to overcome language barriers on the basis of pre-defined and pretranslated workflows. "Regulation (EU) No 1024/2012 of the European Parliament and of the Council of 25 October 2012 on administrative cooperation through the Internal Market Information System and repealing Commission Decision 2008/49/EC ( 'the IMI Regulation')", https://eur-lex.europa.eu/legal-content/EN/TXT/?uri=CELEX\%3A32012R1024, pristupljeno: 23. februar 2021. godine.

27 „Uključujući usluge, profesionalne kvalifikacije, javne komisije, naredbe, delegacije zaposlenih itd." Olgierd Jakubowski, The Internal Market Information System (IMI) on the Return of Cultural Objects - Its Principles, Application, and Evaluation of Its Effectiveness for the Protection of Cultural Heritage, op. cit., p. 298. Autor ističe i to da IMI sistem treba razlikovati od već dobro ustanovljenih baza (registara) podataka o izgubljenim kulturnim objektima. Razlika se povlači na osnovu njihove funkcije: IMI sistem služi za veoma brzu razmenu podataka koji omogućavaju povrat dobara, dok baze podataka samo prikupljaju podatke, kojima uži ili širi krug lica može pristupiti (p. 308). 
je upravo ona predstavljala svojevrstan uzor prilikom oblikovanja Direktive. Treba podvući i to da je Direktiva 2014/60 predviđena samo za države koje zahtevaju povrat kulturnih dobara koja su nelegalno izvezena sa njihove teritorije, dok je UNIDROIT 1995 Konvenciju moguće primeniti i na zahteve fizičkih lica, ukoliko je reč o kulturnom dobru koje je ukradeno, ali i na zahteve država, ukoliko je reč o nelegalnom izvozu. ${ }^{28}$ Jedna od potencijalnih opcija bila je i to da EU kao celina pristupi UNIDROIT 1995 Konvenciji, od čega se odustalo zbog „neizvodljivosti” ${ }^{29}$ Kao rezultat, prihvaćeno je rešenje da se donese nova Direktiva 2014/60 kojom bi se zamenila prethodna.

Dakle, budući da, s jedne strane, EU nije podobna da pristupi UNIDROIT 1995 Konvenciji jer potonja prihvata isključivo države članice, dok se, s druge strane, nadležnosti UNIDROIT Konvencije 1995 i Direktive 2014/60 prepliću u mnogim pitanjima prometa kulturnih dobara, mogu se čuti mišljenja kako celo drugo poglavlje Konvencije (koje se odnosi na ukradena dobra) treba da se inkorporira u Direktivu 2014/60, a u cilju harmonizacije pravnih rešenja. ${ }^{30}$ Situaciju dodatno komplikuje činjenica da je određen broj država članica EU istovremeno i ugovornica UNIDROIT 1995 Konvencije. Postavlja se pitanje da li da postojanje dva paralelna pravna režima koja uređuju povrat kulturnih dobara, a koji su uspostavljeni evropskim i međunarodnim pravnim instrumentom, doprinosi određenoj fragmentisanosti ove oblasti? ${ }^{31}$ No, čak i da je tako, ne treba žuriti sa negativnom ocenom same fragmentacije u ovom kontekstu. Pre svega, Direktiva 2014/60 doneta je po uzoru na UNIDROIT 1995 Konvenciju, te nam one ne nude radikalno različita rešenja. U tom smislu, smatramo da postojanje tzv. ,klauzule 0 isključenju" (disconnection clause) u UNIDROIT 1995 Konvenciji predstavlja

${ }^{28}$ Za više o inovativnim rešenjima UNIDROIT 1995 Konvencije videti: Lyndel Prott, UNIDROIT Convention on Stolen or Illegally Exported Cultural Objects - Ten Years On, Uniform Law Review, 14/1-2, 2009, pp. 215-237;Vanja Pavićević, „Pravni izazovi zaštite kulturnih dobara u Srbiji - usklađivanje sa UNIDROIT Konvencijom o ukradenim ili ilegalno izvezenim predmetima od kulturnog značaja", Saopštenja, Republički zavod za zaštitu spomenika, 2019, str. 217-227.

${ }^{29}$ Marina Schneider, "The 1995 UNIDROIT Convention: An Indispensable Complement to the 1970 UNESCO Convention and an Inspiration for the 2014/60/EU Directive”, op. cit., p. 160.

${ }^{30}$ Prof. Weller ipak ne isključuje mogućnost da EU pristupi UNIDROIT 1995 Konvenciji, a na osnovu ovlašćenja sadržanom u čl. 216 UFEU, kojim EU stiče pravo da zaključuje međunarodne ugovore sa trećim državama ili međunarodnim organizacijama. Videti: Matthias Weller, Rethinking EU Cultural Property Law - Towards Private Enforcement, Nomos Verlag, Germany (Baden-Baden), 2018, p. 81.

${ }^{31} \mathrm{Za}$ više o fragmentaciji međunarodnog i evropskog prava, videti: Branko Rakić, „Fragmentacija međunarodnog prava i evropsko pravo - na zapadu nešto novo”, Anali Pravnog fakulteta u Beogradu, godina LVII, 1/2009, pp. 122-147. 
dovoljan garant u cilju izbegavanja sukoba zakona. Predmetna klauzula predviđa da bilo koja država ugovornica, koja je već član neke organizacije s ciljem ekonomske integracije ili regionalnog tela, a čija pravila uređuju pitanja od značaja za Konvenciju, može da izjavi kako će primenjivati ta unutrašnja pravila umesto odredbi Konvencije. ${ }^{32} \mathrm{Na}$ taj način, država može na osnovu okolnosti svakog konkretnog slučaja da proceni koja je od postojećih pravnih opcija pogodnija za povrat, što u konačnici može samo da doprinese sveobuhvatnijoj zaštiti kulturnih dobara. Stoga, ne smatramo da je postojanje paralelnog pravnog režima u vidu UNIDROIT 1995 Konvencije problematično za Direktivu 2014/60, što se baš i ne može reći za druge instrumente EU koje ćemo analizirati u nastavku.

\subsection{UREDBA EU 116/2009 O IZVOZU KULTURNIH DOBARA}

Uredba EU 116/2009 o izvozu kulturnih dobara (u daljem tekstu kao: Uredba 116/2009), reguliše izvoz kulturnih dobara ka trećim zemljama i zamenila je prethodnu, više puta izmenjenu Uredbu 3911/92 o izvozu kulturnih dobara. ${ }^{33} \mathrm{U}$ cilju očuvanja unutrašnjeg tržišta EU i zaštite kulturnih dobara, Uredba 116/2009 propisuje uslov izdavanja izvozne dozvole, čime se ustanovljava jedinstvena kontrola na spoljnim granicama EU.

Međutim, Uredba 116/90 se kroz ceo svoj tekst poziva na Direktivu 93/7 koja je stavljena van snage, i time stvara zbunjenost u pogledu definicije kulturnog dobra kojem se pruža zaštita. I ne samo to - Uredba 116/90 sadrži aneks kojim se propisuju starosne i finansijske kategorije u koje kulturno treba da se uklopi kako bi dobilo zaštitu prilikom izvoza. Taj aneks je zapravo istovetan već pomenutom aneksu iz Direktive 93/7, koji je u novoj Direktivi 2014/60 napušten (videti poglavlje dva). Iako se u Uredbi 116/90 navodi da će se aneks primenjivati kako bi se kulturnim dobrima koje se uklapaju u njegove kriterijume pružila „naročita zaštita”, a bez predrasuda na definiciju „nacionalnog blaga” od strane država članica, kalupljenje kulturnih dobara u vremenske i finansijske kategorije već se pokazalo kao neadekvatno rešenje. Smislenije rešenje bi bilo da Uredba 116/9 samostalno definiše kulturna dobra i time okonča pravnu nesigurnost u pogledu toga šta se pod kulturnim dobrom podrazumeva, ili da se naknadno harmonizuje sa novom Direktivom 2014/60.

\footnotetext{
${ }^{32}$ Marina Schneider, "The 1995 UNIDROIT Convention: An Indispensable Complement to the 1970 UNESCO Convention and an Inspiration for the 2014/60/EU Directive”, op. cit., p. 159; UNIDROIT Convention on Stolen or Illegally Exported Cultural Objects, Article 13 (3).

33 "Council Regulation (EC) No 116/2009 of 18 December 2008 on the export of cultural goods", OJ L 39, 10.2.2009. Ova Uredba zamenila je prethodnu, Uredbu 3911/92 o izvozu kulturnih dobara.
} 


\subsection{UREDBA EU 1215/2012 O SUDSKOJ NADLEŽNOSTI I PRIZNAVANJU I IZVRSENJU PRESUDA U GRAĐANSKIM I TRGOVINSKIM STVARIMA (BRISEL I IBIS)}

Uredba EU 1215/2012 o sudskoj nadležnosti i priznavanju i izvršenju presuda u građanskim i trgovinskim stvarima - Brisel I Ibis (u daljem tekstu kao: Brisel Uredba) ustanovljava međusobno priznavanje i izvršenje sudskih odluka u građanskim i trgovinskim sporovima sa međunarodnim elementom, a u okviru EU. ${ }^{34}$ Dakle, kao instrument harmonizacije pravila privatnog prava u EU, ona je takođe relevantna i za promet kulturnih dobara. ${ }^{35}$ Naime, Brisel Uredba daje mogućnost vlasniku kulturnog dobra da podnese tužbu za povrat u građanskom postupku pred sudom druge države, ukoliko se dobro u momentu pokretanja postupka nalazilo na teritoriji te druge države ${ }^{36} \mathrm{Na}$ taj način se fizičkim licima omogućava povrat kulturnih dobara kroz proširenje nadležnosti sudova na terenu cele EU.

Međutim, uprkos pozitivnoj harmonizaciji sudske nadležnosti, ponovo je prisutna pojmovna neusklađenost u pogledu kulturnog dobra. Naime, član 7 stav 4 Brisel Uredbe poziva se na definiciju kulturnog dobra iz stare Direktive 93/7, koja pored proglašenja „nacionalnog blaga” od strane država članica, predviđa već pomenute kriterijume iz aneksa, ili pripadnost javnoj zbirci. Predmetno pozivanje je nepotrebno i konfuzno, pogotovo za tako važan instrument kao što je Brisel Ibis, koji je mogao samostalno i precizno da definiše kulturno dobro, ili da bar, u skladu sa izmenom direktive, izmeni i svoje upućivanje na istu. Ovo pogotovo imajući u vidu da ni stara Direktiva 93/07, pa čak ni nova Direktiva 2014/60 ne pokrivaju građanske tužbe, a da Brisel Ibis pokriva isključivo građanske tužbe. ${ }^{37}$ Zaključujemo da, uprkos donošenju nove Direktive 2014/60, 'nepoželjna zaostavština' stare Direktive 93/7 i njenog pratećeg Aneksa posredno ostaje u životu kroz Uredbu 116/90 o izvozu kulturnih dobara, kao i Brisel Uredbu.

\footnotetext{
34 "Regulation (EU) No 1215/2012 of the European Parliament and of the Council of 12 December 2012 on jurisdiction and the recognition and enforcement of judgments in civil and commercial matters", OJ L 351, 20.12.2012.

${ }^{35}$ Radi što preciznije obrade postavljene teme, Brisel Uredbom ćemo se baviti isključivo u kontekstu kulturnih dobara. Za više o istorijatu donošenja, izmenama prvobitne Uredbe, i celokupnom Brisel pravnom režimu videti: Zlatan Meškić, Dženana Radončić, „Uredba (EU) br. 1215/2012 Evropskog parlamenta i Savjeta od 12. decembra 2012. godine o nadležnosti i priznanju i izvršenju sudskih odluka u građanskim i trgovačkim predmetima", Nova Pravna revija, br. 1/2013, str. 46-55.

36 "Regulation (EU) No 1215/2012 of the European Parliament and of the Council of 12 December 2012 on jurisdiction and the recognition and enforcement of judgments in civil and commercial matters", article 17.

${ }^{37}$ Matthias Weller, Rethinking EU Cultural Property Law - Towards Private Enforcement, op. cit., p. 41.
} 


\section{5) ČLAN 36 UFEU - TAČKA SPOTICANJA NA EU MAPI ZAŠTITE KULTURNIH DOBARA?}

Direktiva 2014/60 EU je kao definiciju kulturnog dobra zadržala samo uslov iz člana 36 UFEU, odnosno napustila je primenu aneksa koji je propisivao finansijske i starosne kriterijume, kao i uslov pripadnosti javnoj zbirci. U skladu s tim, član 2 stav 1 Direktive 2014/60 sada glasi: ... „kulturni predmet” znači predmet koji je klasifikovan ili definisan od strane države članice, pre ili nakon njegovog nezakonitog iznošenja sa državne teritorije te države članice, kao deo "nacionalnog blaga umetničke, istorijske ili arheološke vrednosti" prema nacionalnom zakonodavstvu ili u okviru upravnih postupaka, a u smislu člana 36 UFEU. ${ }^{38}$ Prema tome, ova Direktiva treba da obuhvati predmete od istorijskog, paleontološkog, etnografskog, numizmatičkog interesa ili naučne vrednosti, bez obzira na to da li su deo javne ili druge zbirke ili su pojedinačni predmeti, te da li potiču iz redovnih ili tajnih iskopavanja, pod uslovom da su klasifikovani ili definisani kao nacionalno blago. ${ }^{39}$

\subsection{UZDRŽANOST SUDA PRAVDE EVROPSKE UNIJE}

Član 36 UFEU ne pruža detaljnije smernice u tom pogledu, već samo dodaje da takve zabrane ili ograničenja ne smeju predstavljati sredstvo proizvoljne diskriminacije ili prikriveno ograničavanje trgovine između država članica. ${ }^{40}$ Stoga, smernice treba potražiti u tumačenjima Suda, kao najvišeg sudskog autoriteta i tumača ugovora u EU, u proceni da li država članica postupa u skladu sa EU acquis. U sada već čuvenom slučaju Komisija protiv Italije, ${ }^{41}$ italijanska vlada nametnula je porez na izvoz određenih kulturnih dobara od umetničke, istorijske i arheološke vrednosti, tvrdivši da takva dobra ne predstavljaju robu široke potrošnje i da svrha poreza nije prikupljanje prihoda, već isključivo zaštita kulturnog nasleđa zemlje. ${ }^{42}$ Ipak, ovakvi argumenti bili su odbijeni od strane Suda, sa obrazloženjem da se izuzetak može konstituisati samo u odnosu na kvantitativna ograničenja predviđena članom 34 UFEU, te da ne mogu da opravdaju nametanje fiskalnih mera koje su zabranjene članom 30 UFEU $^{43}$ Dakle, Sud je stao na stanovište

38 "Directive 2014/60/EU of the European Parliament and of the Council of 15 May 2014 on the return of cultural objects unlawfully removed from the territory of a Member State and amending Regulation (EU) No 1024/2012 (Recast)", Article 2.

${ }^{39}$ Ibid., Article 9 (preamble).

40 "Such prohibitions or restrictions shall not, however, constitute a means of arbitrary discrimination or a disguised restriction on trade between Member States", član 36 UFEU.

${ }^{41}$ Case 7/68 Commission v Italy [1968] ECR 423.

${ }^{42}$ Paul Philip Craig, Gráinne de Búrca, EU Law: Text, Cases, and Materials, op. cit., p. 613.

${ }^{43}$ Čl. 30 UFEU: „Između država članica zabranjene su carinske dažbine na uvoz i izvoz i dažbine koje imaju isto dejstvo. Ova zabrana takođe se primenjuje na carinske dažbine fiskalne prirode". 
Komisije da je uvedena mera imala efekat, odnosno dejstvo ekvivalentno carini, te je stoga morala biti ukinuta a u skladu sa čl. 16 EEZ ${ }^{44}$ Rezonovanje Suda, s jedne strane, jeste ispravno u kontekstu fiskalnih ograničenja, budući da je Italija zaista nametnula dodatne fiskalne obaveze koje su zabranjene. Podrazumeva se da, kao i ostala ograničenja od slobodnog prometa robe, i ograničenja u pogledu izvoza kulturnih dobara moraju zadovoljiti test neophodnosti, proporcionalnosti i nediskriminacije. ${ }^{45} \mathrm{~S}$ druge strane, Sud je izjednačio 'umetnička dela' sa običnom robom, sa obrazloženjem da je reč o proizvodima koji mogu biti procenjeni u novcu, i koji su samim time podložni prometu robe u skladu sa UFEU. Ne priznajući specifičnost kulturnih dobara, Sud je donekle 'poništio' izuzetak ustanovljen članom 36 UFEU. Terminologija Suda je takođe problematična - izraz 'umetnička dela' ne može biti korišćen kao sinonim za kulturna dobra. Na primer, ulje na platnu amatera-hobiste može imati predznak umetničkog dela, ali će pre ulje na platnu nacionalnog umetnika predstavljati zaštićeno nacionalno blago (određeno kulturno dobro).

Međutim, po pitanju toga šta se tačno podrazumeva pod nacionalnim blagom i šta se može smatrati proizvoljnom diskriminacijom, nailazimo na uzdržanost Suda, koji je uskratio svoje tumačenje predmetnih determinanti. Iako je u ovom slučaju prepoznao da su retencija (zadržavanje) i zaštita dva različita koncepta, ${ }^{46}$ Sud je propustio priliku da u retkom slučaju gde se uopšte postavilo pitanje izuzetka u vidu nacionalnog blaga, pruži smernice koje bi konstituisale legitiman izuzetak u okviru člana 36 UFEU. Sve navedeno govori u prilog veoma uskom tumačenju izuzetka, što potvrđuje i Pjer Peskatore (Pierre Pescatore), sudija Suda koji je učestvovao u odlučivanju, i koji je naknadno objavio članak u kojem je istakao da se izuzeci od pravila koja zabranjuju kontrolu izvoza moraju strogo tumačiti. ${ }^{47}$

\subsection{KRITIČKI OSVRT - SADRŽINA POJMA "NACIONALNO BLAGO"?}

Napuštanje navedenih kriterijuma iz aneksa jeste novina u Direktivi koju treba pohvaliti, budući da su se isti pokazali kao neadekvatni, iako su, nažalost, kao što

\footnotetext{
${ }^{44}$ Ibid.

${ }^{45}$ John E. Putnam II, "Common Markets and Cultural Identity: Cultural Property Export Restrictions in the European Economic Community", University of Chicago Legal Forum, Volume 1992, Issue 1, article 20, p. 472.

${ }^{46}$ John Henry Merryman, "Cultural Property, International Trade and Human Rights", Cardozo Arts \& Entertainment, Vol. 19/ 51, 2001, p. 56. Autor dalje objašnjava pojam zaštite, koji uglavnom podrazumeva zaštitu od određenog oštećenja ili opasnosti, dok retenciju kvalifikuje kao sprečavanje cirkulacije i namerno zadržavanje kulturnog dobra unutar granica zemlje porekla.

${ }^{47}$ Pierre Pescatore, "Le commerce de 1'art et le Marché commun", Revue Trimestrielle de Droit Europeen, Vol. 21/3, 1985, p. 451.
} 
smo videli zadržani u drugim, srodnim instrumentima. Međutim, definicija „nacionalnog blaga” je problematična iz više razloga. Najpre, sama kovanica "nacionalnog blaga koje ima umetničku, istorijsku ili arheološku vrednost” izostavila je reč „kultura”, kao i reč „nasleđe”. Premda se u samoj Direktivi 2014/60 generalno pominje termin „kulturno dobro” (cultural object), definicija „nacionalnog blaga” koja vrši upućivanje na član 36 UFEU izostavlja dati termin. To unosi dodatnu nedorečenost u već problematičnu i složenu terminologiju ove grane prava. Nacionalno blago ne može se izjednačiti sa celokupnim kulturnim nasleđem, kao široko postavljenim pojmom koji obuhvata materijalno i nematerijalno kulturno nasleđe. Izuzetak predviđen u čl. 36 može isključivo da se opravda usvajanjem derogativnih mera koje su baš usmerene na zaštitu konkretnog „nacionalnog blaga”, i koje se ne mogu proširiti na sva druga dobra koja pripadaju „kulturnom nasleđu”. 48

Šta u tom slučaju obuhvata „nacionalno blago"?

Ukoliko najpre analiziramo arhaičnu reč „blago”, složićemo se da ista upućuje na nešto izuzetno, retko i vredno, kako u duhovnom tako i u finansijskom smislu. Čini se da termin aludira na određenu kategoriju dobara koja je vrednosno daleko iznad uobičajene definicije materijalnog, pokretnog kulturnog nasleđa. Vidimo da je uprkos izostavljanju aneksa iz Direktive 2014/60, ipak prisutna određena lestvica vrednosti koju kulturno dobro mora da „premaši” kako bi dobilo zaštitu. Ovde je važno naglasiti da postavljanje uslova samo po sebi ne mora predstavljati problem. Naravno da je neophodno razlučiti kulturna dobra koja mogu biti od značaja za kulturnu politiku konkretne države, s jedne strane, od svih umetničkih predmeta grosso modo nastalih u toj državi, s druge strane. Međutim, jasno razlikovanje nije moguće uspešno izvršiti na osnovu maglovite i nedorečene kovanice kakvo je „nacionalno blago koje ima umetničku, istorijsku ili arheološku vrednost”, a pogotovo imajući u vidu da se izraz „nacionalno blago” ne koristi čak ni u nacionalnim zakonodavstvima država članica EU, niti pri relevantnim međunarodnim organizacijama kao što je npr. UNESCO. Takva definicija nameće teret za države članice jer ih primorava da zaštite samo dobra koja se izuzetno mogu smatrati „blagom”, odnosno koja verovatno nose jako visoku ekonomsku i kulturnu vrednost.

Dalje, insistiranjem na problematičnom pridevu - „nacionalno”, postojećim dilemama dodaje se još veći stepen konfuzije. Šta se podrazumeva pod nacionalnim $?^{49}$ Da li je to zemlja porekla, odnosno zemlja gde je kulturno dobro

\footnotetext{
${ }^{48}$ Manlio Frigo, Circulation des biens culturels détermination de la loi applicable et méthodes de règlement des litiges, Académie de Droit International de La Haye, 2016, p. 307.

${ }^{49}$ Slikovit primer problematike koju nosi ovaj pridev može biti i čuveni slučaj Partenonskih skulptura, oko kojih su Grčka i Ujedinjeno Kraljevstvo u dugogodišnjem sporu. Obe zemlje
} 
nastalo, ili je reč o državljanstvu/poreklu samog umetnika koji je stvorio kulturno dobro? ${ }^{50}$ Ili je reč o kulturnim dobrima koja uživaju neku posebnu zaštitu zato što, na primer, reflektuju izuzetan doprinos nekog nacionalnog umetnika, ili su važna za nacionalni i kulturni identitet države, nezavisno od porekla umetnika?

Sa druge strane, države imaju skoro neograničenu slobodu da značajan deo svojih kulturnih dobara proglase za nacionalno blago, a imajući u vidu njihovu samostalnost u definisanju i zaštiti svog kulturnog nasleđa. To prirodno može voditi ka određenim zloupotrebama, tako što će države znatno proširiti opseg „nacionalnog blaga”, i time indirektno nametnuti kvantitativna ograničenja slobodnom prometu robe. Na primer, Italija je zemlja koja se odlikuje izuzetno restriktivnim izvoznim kontrolama kulturnih dobara, i gde italijansko ministarstvo obrazovanja poseduje pravo preče kupovine na prodaju bilo kog umetničkog dela, bilo domaćim ili stranim kupcima. ${ }^{51}$ Na taj način, Ministarstvo stiče mogućnost da obustavi bilo koju transakciju i kupi dati objekat u ime države. ${ }^{52}$ Međutim, preterano ekstenzivnom zaštitom kulturnih dobara od strane države ne samo što se ugrožava sloboda kretanja robe i funkcionisanje jedinstvenog tržišta već se, nažalost, indirektno podstiču i transakcije na crnom tržištu. Činjenica da su neke kategorije dobara teže dostupne za kupovinu neće dovesti do smanjenja potražnje za njima, naprotiv, često će ih učiniti još traženijim. Privatni kolekcionari i privatni muzeji, mada čak i nacionalni muzeji, ne ustručavaju se da po svaku cenu nabave određeno dobro i uključe ga u svoju zbirku. Tendencija nabavljanja kulturnih dobara putem nezakonitih transakcija predstavlja konstantnu tržišnu pojavu koja sa godinama doživljava veliki procvat. Upravo imajući u vidu ogromnu slobodu država pri definisanju nacionalnog blaga, često se ističe kako je za uspešan povrat kulturnog dobra ključno međusobno „aktivno poverenje” između država, a u pogledu sposobnosti svake od njih da razumno i pošteno odredi šta ta definicija

\footnotetext{
smatraju da je reč o njihovom nacionalnom blagu - Grčka zbog činjenice da predstavlja zemlju porekla, a Ujedinjeno Kraljevstvo zbog značaja koje su skulpture odigrale u nacionalnom i kulturnom životu zemlje, tokom višedecenijskog 'života' u Britanskom muzeju. Za više o stavu da je reč o britanskom nacionalnom blagu, videti: John Henry Merryman, "Thinking about the Elgin Marbles", Michigan Law Review, Vol. 83, No. 8, 1985, pp. 1880-1923; Za više o tački gledišta koju zastupa Grčka, Michael J. Repas, "The Deflowering of the Parthenon: A Legal and Moral Analysis on Why the Elgin Marbles Must be Returned to Greece", The Fordham Intellectual Property, Media and Entertainment Law Journal, Vol. 9, 1998-1999.

${ }^{50}$ John Henry Merryman, "Cultural Property, International Trade and Human Rights", op. cit., p. 55.

${ }^{51}$ John E. Putnam II, "Common Markets and Cultural Identity: Cultural Property Export Restrictions in the European Economic Community", op. cit., pp. 462-463.

${ }^{52}$ Ibid.
} 
obuhvata..$^{53}$ Uvođenje nepoznatog termina, u već složenu oblast kulturnog nasleđa, ne samo što dovodi u pitanje međusobno poverenje država članica već i otežava proces identifikacije i povrata kulturnog dobra.

\section{3. 'POTRAGA' ZA NACIONALNIM BLAGOM - IZGUBLJENO U PREVODU?}

Prethodno analiziranu materijalnu, odnosno supstancijalnu nedorečenost pojma „nacionalno blago” prati i svojevrsna jezička konfuzija. Iako se, na prvi pogled, terminološke nedoumice ne moraju uvek kvalifikovati kao ozbiljniji pravni problem, situacija je posve složenija ukoliko uzmemo u obzir mnoštvo jezika na koje se EU dokumenti prevode. Profesor Frigo (Manlio Frigo) često u svom radu ukazuje na bitne razlike koje sa sobom nose različiti prevodi istog dokumenta, $\mathrm{u}$ ovom slučaju člana 36 UFEU. Naime, prema španskom, italijanskom i portugalskom zakonodavstvu, termin nacionalno blago definisan je veoma široko: patrimonio artistico, storico o archeologico nazionale/patrimonio artistico, historico o arqueologico nacional/património nacional de valor artistico, histórico ou arqueológico, što bi sve u slobodnom prevodu moglo da se shvati kao 'nasleđe.54 Korišćenjem tako ekstenzivno postavljene definicije državama se ostavlja šira diskreciona moć pri odlučivanju koja će kategorija dobara biti uključena u nacionalno 'zaštitno' zakonodavstvo, kao i kakva će tačno biti njihova ograničenja prilikom prometa. ${ }^{55} \mathrm{~S}$ druge strane, engleska i francuska verzija koriste restriktivnije termine - national treasures of artistic, historic or archaeological value, trésors nationaux ayant une valeur artistique, historique ou archéologique, gde ipak preciziraju da je reč o određenom 'blagu', a ne o celokupnom nasleđu jedne zemlje. ${ }^{56}$

Različiti prevodi istog teksta, zajedno sa uzdržanošću Suda, stvaraju nepotrebnu terminološku i materijalnu pravnu nesigurnost. Takođe, bez hrabrijeg, preciznijeg i usklađenijeg razgraničenja pojma nacionalno blago, postoji mogućnost da će veliki broj prijava koje se unose u IMI sistem završiti kao

\footnotetext{
${ }^{53}$ Michele Graziadei, Barbara Pasa, "The Single European Market and Cultural Heritage: The Protection of National Treasures in Europe", in Andrzej Jakubowski, Kristin Hausler, Francesca Fiorentini, (eds.), Cultural Heritage in the European Union, A Critical Inquiry into Law and Policy, Koninklijke Brill NV, Leiden, The Netherlands, 2019, p. 92.

${ }^{54}$ Italijanski prevod Direktive 2014/60, član 2 i ostali. https://eur-lex.europa.eu/legalcontent/IT/TXT/PDF/?uri=CELEX:32014L0060\&from=EN , pristupljeno 15.3.2021. godine.

${ }^{55}$ Manlio Frigo, "Cultural property v. cultural heritage: A battle of concepts in international law?", International Review of the Red Cross, no. 854, 2004, pp. 371-372.

${ }^{56}$ Ibid., Nemački prevod teksta se razlikuje, te koristi termin 'kulturna dobra': "Kulturgu[t] von klnstlerischem, geschichtlichem oder archaologischem Wert".
} 
neuspešne, odnosno da sistem neće prepoznati kategoriju kulturnih dobara kojima je potrebna zaštita. ${ }^{57}$ Preostaje nam da član 36 UFEU posmatramo kroz prizmu teleološkog tumačenja - intencija evropskog zakonodavca je verovatno i bila da se terminološki napravi jedan vrednosni prag koji malo koje kulturno dobro može ispuniti, a u cilju što užeg tumačenja eventualnih izuzetaka od generalne zabrane kvantitativnog ograničenja slobode prometa robe u EU.

\section{6) ZAKLJUČNA RAZMATRANJA}

Mnogi autori ističu da kulturno nasleđe u ekonomskom smislu predstavlja samo običnu robu, odnosno ekonomsko dobro, tako da uporni pokušaji da se kulturno dobro 'zaštiti' (tako što će se pozicionirati iznad obične robe) neće dovesti do smanjene tržišne potražnje, već upravo suprotno - do stvaranja crnog tržišta. ${ }^{58}$ Ipak, smatramo da se kulturno dobro razlikuje od robe, obične stvari za komercijalnu upotrebu (commodity), a na osnovu vrednosti koje su otelotvorene u samom kulturnom dobru. Takve vrednosti mogu biti edukativnog, umetničkog, istorijskog, naučnog, arheološkog, estetskog ili nekog drugog značaja, i upravo ga one čine kulturnim dobrom, premda se naravno ne isključuje postojanje i materijalnih vrednosti. Dakle, duhovna dimenzija kulturnog dobra jeste njegova differentia specifica u odnosu na običnu robu. Istorija je protkana brojnim primerima gde su kulturna i umetnička dobra uživala posebnu pravnu kategoriju..$^{59}$

Sa druge strane, naravno da je u cilju funkcionisanja jedinstvenog tržišta neophodno da se eventualni izuzeci tumače proporcionalno, i u skladu s ciljem koji se želi postići. Međutim, ukoliko pogledamo sam koncept povrata kulturnog dobra, vidimo da Direktiva 2014/60 podržava legis originis pravilo, odnosno povrat kulturnog dobra u zemlju njegovog porekla. Na taj način potvrđuje se određena fizička ali i pravna povezanost između dobra i 'njene' zemlje u koju treba da se vrati. ${ }^{60}$ Time je Direktiva na nivou privatnog prava potvrdila posebnost kulturnih dobara u odnosu na „običnu robu." ${ }^{11}$ Imajući u vidu upravo tu specifičnost koju

${ }^{57}$ Michele Graziadei, Barbara Pasa, "The Single European Market and Cultural Heritage: The Protection of National Treasures in Europe", op. cit., p. 93

${ }^{58}$ Craig Forrest, International Law and the Protection of Cultural Heritage, Routledge, New York, 2010, pp. 5-6.

${ }^{59}$ Rimsko pravo je predviđalo brojne instrumente usmerene ka zaštiti imovine za koju se smatralo da poseduje poseban umetnički značaj. Vidi više: Andrea Biondi, "Merchant, the Thief and the Citizen: The Circulation of Works of Art within the European Union", Common Market Law Review Vol. 34, 1997, pp. 1177.

${ }^{60}$ Dr. sc. Hano Ernst, Kristijan Poljanec, „Stvarnopravna i carinskopravna zaštita kulturnih dobara u svjetlu europske antiterorističke politike", Zbornik Pravnog fakulteta Sveučilišta u Rijeci, Vol. 38, br.1, 2017, p. 208.

${ }^{61}$ Ibid. 
kulturna dobra poseduju, kao i višestruki značaj koje ista imaju za državu, bilo bi poželjno da je Sud pružio preciznije smernice državama članicama u pogledu toga šta može biti proglašeno za izuzetak u okviru člana 36 UFEU. Time bi, s jedne strane, motivisao države članice da usavrše sopstvena zakonodavstva i jasnije odrede šta za njih konkretno predstavlja nacionalno blago, čime bi se pružila veća zaštita kulturnom nasleđu generalno. S druge strane, takvim smernicama države članice bi bile ograničene u ekstenzivnom definisanju svog nacionalnog blaga i pokušaju da zloupotrebe izuzetak, čime bi Sud potvrdio jedinstvenost u postupanju zajedničkog tržišta i carinske unije.

Nedorečenost Suda u stopu prati nedorečenost u delovanju evropskog zakonodavca. Ne može se osporiti da Direktiva 2014/60 svakako jeste postigla bolji kompromis između principa slobodnog prometa robe i zaštite kulturnog nasleđa u odnosu na svoju prethodnicu, kao i da je olakšala postupak povrata kulturnog dobra u finansijskom, administrativnom i pravnom smislu. Ne treba zanemariti ni inovativan informacioni sistem komunikacije između država članica koji umnogome može olakšati razmenu relevantnih podataka. Takođe, tačno je i to da je samo donošenje legislativnih instrumenata važno za generalno podizanje svesti o važnosti zaštite kulturnih dobara. To pogotovo imajući u vidu sve više odgovorniji pristup kulturnom nasleđu koji prate brojni slučajevi dobrovoljnog povrata kulturnih dobara od strane zemalja koje nisu čak ni pravno obuhvaćene zakonodavstvom EU. ${ }^{62}$ No, uprkos činjenici da Direktiva 2014/60 jeste pravno poboljšana, i da je obavezama koje predviđa donekle emancipovala umetničko tržište, sâm čin njenog pozivanja na član 36 UFEU i spornu definiciju nacionalnog blaga ostaje tačka spoticanja na mapi zaštite kulturnih dobara. Drugim rečima, veza između člana 36 UFEU i Direktive 2014/60 nije 'samo' terminološka, već se nedorečenost datog člana, nažalost, proteže na celokupan pravni okvir povrata kulturnih dobara. Ukoliko na sve to dodamo i činjenicu da se Uredba 116/90 i Brisel Uredba i dalje pozivaju na definiciju kulturnog dobra iz nevažeće Direktive 93/7 i njen zastareli aneks, možemo zaključiti da oblast zaštite i povrata kulturnih dobara u EU sadrži određen stepen neujednačenosti.

Međutim, ukoliko se aneks koji postavlja starosne i vrednosne uslove za kulturna dobra pokazao kao neadekvatan, izostavivši svojim strogim kriterijumima veliki broj kulturnih dobara, dok se neodređena definicija nacionalnog blaga pokazala kao preširoka, ne pružajući jasne smernice u pogledu konstituisanja opravdanog izuzetka, postavlja se pitanje šta bi predstavljalo adekvatno rešenje u ovom pogledu? Činjenica je da nije lako pronaći taj delikatan balans između zaštite kulturnih dobara i proklamovane slobode prometa robe u EU. U naučnoj zajednici

${ }^{62} \mathrm{Geo}$ Magri, "The impact of the UNESCO and UNIDROIT Conventions and the EU directives on the international art market: an analysis fifty years after the introduction of the obligation to return stolen or illegally exported cultural goods", op. cit., p. 72. 
mogu se čuti raznovrsni predlozi po ovom pitanju. Prof. Weller predlaže zanimljivo rešenje, a to je uvođenje generalne nadležnosti EU za pokretne stvari (in rem), koja se ne bi ograničila samo na kulturna dobra. ${ }^{63}$ Biondi ukazuje da je kulturno nasleđe neraskidivo povezano sa obrazovanjem i kulturnim pravima, koji predstavljaju fundamentalne aspekte zrelog koncepta evropskog građanstva. ${ }^{64} \mathrm{U}$ skladu s tim, na jedan duhovit i ilustrativan način postavlja pitanje čije će interese EU zajednica uvažiti: trgovca, lopova ili evropskih građana ${ }^{65}$ Drugi smatraju, donekle ispravno, da akademska diskusija nije dovoljna, već da je neophodna zvanično pojašnjenje Suda u vidu daljih smernica. ${ }^{66}$

Iako je Sud po tom pitanju ostao uzdržan, a ni EU zakonodavstvo nije zauzelo odlučniji stav, čini se da bar države članice mogu doprineti svojim nacionalnim zakonodavstvima većoj jasnoći i uređenosti po ovom pitanju. Na primer, Ujedinjeno Kraljevstvo ima interesantno rešenje, gde savetodavni komitet sačinjen od stručnjaka iz različitih oblasti, odlučuje da li se određeno kulturno dobro može kvalifikovati kao 'nacionalno blago', odnosno da li mu treba dozvoliti ili odbiti izvoz. ${ }^{67}$ Takvu odluku donosi uzimajući u obzir tzv. 'Vejverli kriterijume'. (Waverly Criteria), a koji uzimaju u obzir povezanost konkretnog dobra sa britanskom istorijom kulturom i nacijom..$^{68}$ Južna Koreja je takođe zauzela odgovoran pristup - južnokorejska vlada je kreirala preciznu listu materijalnog kulturnog nasleđa, artefakata, nalazišta i zgrada koja su prepoznata od strane nacije kao blaga koja imaju izuzetnu umetničku, kulturni i istorijsku vrednost. ${ }^{69}$ Holandija npr. ima veoma jednostavno rešenje: kulturna dobra u javnom, državnom vlasništvu, uglavnom nisu podobna za slobodan promet. ${ }^{70}$ Stoga, holandski Akt o očuvanju kulturne baštine (The Conservation of Cultural Heritage Act) ovlašćuje vladu da

${ }^{63}$ Ibid., p. 46.

${ }^{64}$ Andrea Biondi, "Merchant, the Thief and the Citizen: The Circulation of Works of Art within the European Union", op. cit., p. 1195.

${ }^{65}$ Ibid.

${ }^{66}$ Jia Min Cheng, "The Problem of National Treasure in International Law", Oregon Review of International Law, Vol. 12, 2010, p. 172.

67 "Statutory Guidance on the Criteria to be taken into consideration when making a decision about whether or not to grant an export licence", Department for Culture, Media and Sport, https://www.artscouncil.org.uk/sites/default/files/download-file/Export_criteria_ March_2015.pdf, pristupljeno: 10.5.2021. godine.

${ }^{68}$ John E. Putnam II, "Common Markets and Cultural Identity: Cultural Property Export Restrictions in the European Economic Community", op. cit., p. 459.

${ }^{69}$ Jia Min Cheng, "The Problem of National Treasure in International Law", op. cit., p. 155.

${ }^{70}$ John E. Putnam II, "Common Markets and Cultural Identity: Cultural Property Export Restrictions in the European Economic Community", op. cit., p. 461. 
sastavi listu kulturnih dobara u privatnom vlasništvu koju će kontrolisati, a koja su od velikog značaja za nacionalno nasleđe. ${ }^{71}$

Dakle, smatramo da bi dobro rešenje u ovom pogledu bilo eksplicitno definisanje 'nacionalnog blaga' od strane svih država članica. Na taj način bi se podvukla jasna razlika između umetničkih dela en général, i onih kulturnih dobara koje država želi da klasifikuje kao svoja 'nacionalnog blaga'. Time bi, u slučaju spora, Sud bio onemogućen da sa plitkim obrazloženjem izjednači ta dva pojma, kao što je učinio u slučaju Komisija v Italija. Naravno, definisanje 'nacionalnog blaga' unapred od strane države članice ne predstavlja garant da će izuzetak biti uvažen od strane EU institucija, a pogotovo imajući u vidu velike razlike u kulturi, tradiciji i vrednostima između samih država članica, kao i razlike u vođenju njihove kulturne politike. No, preventivnim i jasnim definisanjem država ipak postupa odgovornije prema svom nasleđu, te se njena namera da kulturno dobro zaštiti može protumačiti ozbiljnije od strane Suda. U suprotnom, kada država iskoristi pravo preče kupovine tek onda kada već nastupi opasnost da kulturno dobro napusti zemlju, odnosno kada država naknadno pruži zaštitu dobru za koje se već traži izvozna licenca, njen postupak može ukazivati na zloupotrebu izuzetka iz člana $36 .^{72}$

\section{7) ZNAČAJ ZA REPUBLIKU SRBIJU}

Republika Srbija trenutno nema Zakon o kulturnom nasleđu, premda je radna grupa oformljena i u toku je proces održavanja javnih rasprava. Stoga se možemo okrenuti postojećem zakonu, a to je Zakon o kulturnim dobrima (u daljem tekstu: Zakon). ${ }^{73}$ Prema Zakonu, kulturna dobra, u zavisnosti od fizičkih, umetničkih, kulturnih i istorijskih svojstava, mogu biti pokretna i nepokretna. Pokretna

\footnotetext{
${ }^{71}$ Ibid.

${ }^{72}$ Postoji mnoštvo primera koji ilustruju naknadno prisvajanje određenog kulturnog dobra od strane države, nakon što se neko zainteresovao za predmetno dobro. Npr. italijanska vlada je odlučila da po hitnom postupku kupi Van Gogovu sliku „Portret mladog seljaka” (Portrait of a Young Peasant, poznatu i kao Baštovan - The Gardener), tek nakon što je vlasnik slike, Gugenhajm muzej (the Guggenheim Museum), podneo zahtev za izvoznu dozvolu. Slučaj je izazvao dosta kontroverzi, okončavši se intervencijom italijanskog ustavnog suda koji je pak potvrdio ustavnost prava preče kupovine. Slučaj je otišao čak do Evropskog suda za ljudska prava, koji je potvrdio pravo italijanske države da otkupi sliku, ali je konstatovao da se Italija neosnovano obogatila, plativši nižu cenu od tržišne. Vidi više: Andrea Biondi, "Merchant, the Thief and the Citizen: The Circulation of Works of Art within the European Union", p. 1181; Arthemis, Portrait of a Young Peasant - Beyeler v. Italy, https://plone.unige.ch/art-adr/casesaffaires/portrait-of-a-young-peasant-2013-beyeler-v-italy, pristupljeno: 10.5.2021. godine.

${ }^{73}$ Zakon o kulturnim dobrima, Službeni glasnik RS, br. 71/94, 52/2011 - dr. zakoni, 99/2011 dr. zakon i 6/2020 - dr. zakon).
} 
kulturna dobra obuhvataju umetničko-istorijska dela, arhivsku građu, filmsku građu i stare i retke knjige. ${ }^{74} \mathrm{U}$ zavisnosti od svog značaja, mogu se razvrstati u sledeće kategorije: kulturna dobra, kulturna dobra od velikog značaja i kulturna dobra od izuzetnog značaja. ${ }^{75}$ Svakako za sve tri kategorije dobra možemo reći da su značajne za kulturu Republike Srbije, što uostalom dovoljno za sebe i govori čin proglašenja za kulturna dobra. Međutim, postavlja se interesantno pitanje, a to je - koja od tri navedene kategorije bi mogla da se uzme u razmatranje kao eventualni izuzetak od slobode prometa robe, odnosno u koju kategoriju kulturno dobro treba da pripadne kako bi, prema EU institucijama, moglo biti definisano kao nacionalno blago? To je svakako izazovno i teško pitanje, koje pred stručnjake postavlja zahtevan zadatak, odnosno vrednosno ocenjivanje, šta je kulturno 'značajno', a šta je 'značajnije'? Ukoliko uzmemo u obzir, s jedne strane, da se prema tumačenju Suda pravde EU nacionalno blago ne može izjednačiti sa celokupnim kulturnim nasleđem, pa ni sa svim pokretnim kulturnim dobrima jedne zemlje, a da je, s druge strane, za označavanje nekog kulturnog dobra kao 'nacionalnog blaga' prema standardima EU institucija potreban visok vrednosni prag, čini se da su potonje dve kategorije - kulturna dobra od velikog i kulturna dobra od izuzetnog značaja - pogodne za dalju analizu.

U Republici Srbiji, pokretno kulturno dobro od velikog značaja jeste ono dobro koje je značajno za određeno područje ili razdoblje, ili koje svedoči o društvenim ili prirodnim pojavama, odnosno uslovima društveno-ekonomskog i kulturnoistorijskog razvoja u određenim razdobljima, ili koje svedoči o značajnim događajima i istaknutim ličnostima iz nacionalne istorije, a koje utvrđuju Narodni muzej u Beogradu, Arhiv Srbije, Narodna biblioteka Srbije i Jugoslovenska kinoteka. ${ }^{76}$ Uslovi za posedovanje velikog značaja postavljeni su alternativno. Ukoliko posmatramo date uslove, možemo zaključiti da je za standard 'nacionalnog blaga' (premda nedorečen) potrebna veoma jaka veza između kulturnog dobra i države, te bi se verovatno zahtevalo više od datog svedočenja. Kulturna dobra od izuzetnog značaja, s druge strane, jesu ona dobra koja imaju poseban značaj za društveni, istorijski i kulturni razvoj naroda u nacionalnoj istoriji, odnosno za razvoj njegovog prirodnog okruženja, ili koja svedoče o presudnim istorijskim događajima i ličnostima i njihovom delovanju u nacionalnoj istoriji, ili koja predstavljaju jedinstvene (raritetne) primerke stvaralaštva svog vremena, ili jedinstvene primerke iz istorije prirode, ili koja imaju veliki uticaj na razvoj društva, kulture, tehnike i nauke. ${ }^{77}$ Njih utvrđuje Narodna skupština, a na predlog već pomenutih nadležnih ustanova koje, svaka za sebe, vode centralni registar iz svoje

\footnotetext{
${ }^{74}$ Ibid., član 2.

${ }^{75}$ Ibid.

${ }^{76}$ Ibid., član 5 i 56.

${ }^{77}$ Ibid.
} 
nadležnosti. Čini se da bi kategorija kulturnih dobara od izuzetnog značaja, bila najpodobnija da se kvalifikuje kao kandidat za ispunjenje standarda 'nacionalnog blaga' (kao što je npr. Miroslavljevo jevanđelje.) U svakom slučaju, smatramo da je uspostavljanje posebnog stručnog tela kao 'posrednika' između nadležnih ustanova koje predlažu kulturna dobra od izuzetnog značaja, s jedne strane, i Narodne skupštine koja ih utvrđuje, $s$ druge, unelo dodatnu sigurnost $u$ ispravnost procene takvih nominacija. Takvo telo bi se sastojalo od stručnjaka iz relevantnih oblasti (po mogućstvu i pravnika), i ono bi bilo ovlašćeno da na osnovu jasno definisanih kriterijuma odlučuje o predlozima institucija, a pre prosleđivanja istih zakonodavnoj vlasti.

Imajući u vidu status Republike Srbije kao kandidata za članstvo u EU, kao i obavezu harmonizacije nacionalnog zakonodavstva sa EU acquis koja iz toga proističe, predmetno istraživanje nosi dvostruki značaj - $s$ jedne strane, ono pruža detaljnu analizu pravnog okvira povrata kulturnih dobara u EU, sa kritičkim osvrtom na koncept 'nacionalnog blaga'. S druge strane, budući da je Republika Srbija zemlja izuzetno bogata kulturnim nasleđem, smatramo korisnim da se nadležni organi detaljnije upoznaju sa dinamikom prometa kulturnih dobara u EU, a u svetlu donošenja novog Zakona o kulturnom nasleđu. Konačno, istraživanje se uklapa u rastuće međunarodne, ali i regionalne tendencije bavljenja temom povrata kulturnih dobara, dok na nacionalnom nivou predstavlja tematsku akademsku novinu.

\section{8) LITERATURA (MONOGRAFIJE, ZBORNICI, NAUČNI RADOVI)}

Bator, M. Paul, The International Trade in Art, The University of Chicago Press, Chicago, 1981.

Biondi, Andrea, "Merchant, the Thief and the Citizen: The Circulation of Works of Art within the European Union", Common Market Law Review Vol. 34, 1997, pp. 1173-1195.

Chechi, Alessandro, "The Return of Cultural Objects Removed in Times of Colonial Domination and International Law: The Case of the Venus of Cyrene", Italian Yearbook of International Law, Vol. XVIII, 2008, pp. 159-181.

Cheng, Jia Min, "The Problem of National Treasure in International Law", Oregon Review of International Law, Vol. 12, 2010, pp. 141-174.

Craig, Paul Philip, de Búrca, Gráinne, EU Law: Text, Cases, and Materials, $5^{\text {th }}$ edition, Oxford University Press, New York, 2011.

Ernst, Hano, Poljanec, Kristijan, „Stvarnopravna i carinskopravna zaštita kulturnih dobara u svjetlu europske antiterorističke politike", Zbornik Pravnog fakulteta Sveučilišta u Rijeci, Vol. 38, br. 1, 2017, pp. 187-222. 
Evropsko zakonodavstvo, br. 76/2021

Forrest, Craig, International Law and the Protection of Cultural Heritage, Routledge, New York, 2010.

Frigo, Manlio, "Cultural property v. cultural heritage: A battle of concepts in international law?", International Review of the Red Cross, no. 854, 2004, pp. 367-378.

Frigo, Manlio, Circulation des biens culturels détermination de la loi applicable et méthodes de règlement des litiges, Académie de Droit International de La Haye, 2016.

Frigo, Manlio, "The Implementation of Directive 2014/60/EU and the Problems of the Compliance of Italian Legislation with International and EU Law", Santander Art and Culture Law Review, 2/2016 (2), pp. 71-84.

Graziadei, Michele, Pasa, Barbara, "The Single European Market and Cultural Heritage: The Protection of National Treasures in Europe", in Andrzej Jakubowski, Kristin Hausler, Francesca Fiorentini, (eds.), Cultural Heritage in the European Union, A Critical Inquiry into Law and Policy, Koninklijke Brill NV, Leiden, The Netherlands, 2019.

Jakubowski, Olgierd, "The Internal Market Information System (IMI) on the Return of Cultural Objects - Its Principles, Application, and Evaluation of Its Effectiveness for the Protection of Cultural Heritage", Santander Art and Culture Law Review, 2/2016 (2), pp. 290-312.

Magri, Geo, "Directive 2014/60/EU and Its Effects on the European Art Market", Santander Art and Culture Law Review, 2/2016 (2), pp. 195-210.

Magri, Geo, "The impact of the UNESCO and UNIDROIT Conventions and the EU directives on the international art market: an analysis fifty years after the introduction of the obligation to return stolen or illegally exported cultural goods", Brazilian Journal of International Law, Vol. 17, no. 3, 2020, pp. 61-74.

Weller, Matthias, Rethinking EU Cultural Property Law - Towards Private Enforcement, Nomos Verlag, Germany (Baden-Baden), 2018.

Merryman, John Henry, "Cultural Property, International Trade and Human Rights", Cardozo Arts \& Entertainment, Vol. 19/ 51, 2001, pp. 51-67.

Merryman, John Henry, “Thinking about the Elgin Marbles”, Michigan Law Review, Vol. 83, No. 8, 1985, pp. 1880-1923.

Meškić, Zlatan, Radončić, Dženana, “Uredba (EU) br. 1215/2012 Evropskog parlamenta i Savjeta od 12. decembra 2012. godine o nadležnosti i priznanju i izvršenju sudskih odluka u građanskim i trgovačkim predmetima", Nova Pravna revija, br. 1/2013, str. 46-55.

Pavićević, Vanja, „Pravni izazovi zaštite kulturnih dobara u Srbiji - usklađivanje sa UNIDROIT Konvencijom o ukradenim ili ilegalno izvezenim predmetima od 
kulturnog značaja", Saopštenja, Republički zavod za zaštitu spomenika, 2019, pp. 217-227.

Pescatore, Pierre, "Le commerce de 1'art et le Marché commun", Revue Trimestrielle de Droit Europeen, Vol. 21/3, 1985, pp. 451-462.

Prott, Lyndel, UNIDROIT Convention on Stolen or Illegally Exported Cultural Objects - Ten Years On, Uniform Law Review, 14/1-2, 2009, pp. 215-237.

Putnam II, John E, "Common Markets and Cultural Identity: Cultural Property Export Restrictions in the European Economic Community", University of Chicago Legal Forum, Volume 1992, Issue 1, article 20, pp. 457-476.

Rakić, Branko, „Fragmentacija međunarodnog prava i evropsko pravo - na zapadu nešto novo", Anali Pravnog fakulteta u Beogradu, godina LVII, 1/2009, pp. 122147.

Repas, Michael J., "The Deflowering of the Parthenon: A Legal and Moral Analysis on Why the Elgin Marbles Must be Returned to Greece", The Fordham Intellectual Property, Media and Entertainment Law Journal, Vol. 9, 1998-1999.

Schneider, Marina, "The 1995 UNIDROIT Convention: An Indispensable Complement to the 1970 UNESCO Convention and an Inspiration for the 2014/60/EU Directive", Santander Art and Culture Law Review, 2/2016 (2), p. 149-164.

\section{PROTECTION OF NATIONAL TREASURE AS AN EXEMPTION FROM THE FREEDOM OF MOVEMENT OF GOODS IN THE EU}

Summary: Freedom of movement of goods in the European Union represents the key freedom necessary for the development of customs unions and the single market. With its broad interpretation of quantitative restrictions and measures of equivalent effect, the delineation of direct and indirect discrimination in the EU market, the Court of Justice of the EU has played an important role in the protection of the free movement of goods. Accordingly, to avoid possible abuses, any kind of exception must be interpreted narrowly. Exceptions to the free movement of goods mainly relate to reasons of public morality, safety, protection of health and life of people, animals, plants, but they can also refer to the protection of cultural objects of the state which are classified as "national treasure". In the latter, the Court refrained from providing some general guidelines in interpreting Article 36, which states an exception in the form of a national treasure having artistic, historical or archaeological value. Therefore, the subject of this paper is to find a delicate balance between the proclaimed freedom of movement of goods in the EU and the specific protection of cultural objects. First of all, the existing legal framework for the return of cultural goods to the EU will be analyzed. Next, we will explore the 
connection of the mechanisms for the return of cultural goods with the concept of a national treasure in light of Article 36 TFEU. Finally, the concept of "national treasure" as an exception from the freedom of movement of goods will be critically examined. Hence, the role of European legislation in the development of a wider network for the protection of cultural objects will be presented.

Keywords: Directive 2014/60/EU, return of cultural objects, national treasure, free movement of goods, UNIDROIT 1995. 